\title{
INFLUENCE OF AEROSOL PARTICLE CONCENTRATION ON VOLUMETRIC ACTIVITIES OF INDOOR RADON PROGENY
}

\author{
D. Jasaitis and A. Girgždys \\ Vilnius Gediminas Technical University, Saulètekio 11, LT-10223 Vilnius, Lithuania \\ E-mail: dainius.jasaitis@vgtu.lt
}

Received 13 April 2011; revised 26 May 2011; accepted 21 June 2011

\begin{abstract}
The influence of aerosol particle concentration on changes of volumetric activities of radon short-lived decay products was investigated. Volumetric activities of radon short-lived products in accommodations under various living conditions were measured. Concentrations of aerosol particles in the air, equilibrium factors, and unattached fraction were determinated under normal living conditions and by increasing the concentration of aerosol particles in the air of the accommodations. An increase of radon short-lived decay products attached to aerosol particles was obtained during a candle or frankincence burn, in smokefilled compartments, or in steamy kitchen conditions, therefore larger volumetric activity of the alpha particles was registered. Negative correlation coefficient between unattached fraction and the radioactive equilibrium factor, as well as positive correlation coefficient between the radioactive equilibrium factor and aerosol particle concentration in the air of accommodations has been determined. Seasonal changes of the radioactive equilibrium factor are presented.
\end{abstract}

Keywords: radon, short-lived decay products, volumetric activity, aerosol particle, radioactive equilibrium factor, unattached fraction factor

PACS: 23.60.+e, 89.40.Dd, 89.60.Ec

\section{Introduction}

Radon has a relatively long half-life (3.824 days), therefore its health hazard is relatively smaller than that expected from its short-lived daughters: ${ }^{218} \mathrm{Po}$ (half-life 3 minutes), ${ }^{214} \mathrm{~Pb}$ (27 minutes), ${ }^{214} \mathrm{Bi}$ (20 minutes), and ${ }^{214} \mathrm{Po}(164 \mu \mathrm{s})$.

The inhalation of radon decay products depends not only on their concentration in the air but also on the amount of the decay products that is attached to the aerosol particles [1].

The larger the amount of aerosol particles in the air, the larger part of radon progeny settle on these particles but not on furniture, walls, or curtains. Thus, there are more dangerous radon short-lived decay products in a "dusty" room than in a "clean" room with the same concentration of radon in the air [1, 2].

The effect of radon progeny on health depends on its behaviour in the accommodations. There are two forms of decay products: "unattached to aerosol particles" (the diameter of their diffusion equivalent is from 0.5 to $5 \mathrm{~nm}$ ), and "attached to aerosol particles" (diameter from 5 to $3000 \mathrm{~nm}$ ) [2].

Separate research of ${ }^{222} \mathrm{Rn}$ decay products attached and unattached to the aerosol particles was not carried out. However, it is important to evaluate the amount of nuclides attached and unattached to aerosol particles in premises because due to different diffusion of molecules the short-lived decay products settle in different places of the airway and in different amounts.

The concentration of ${ }^{222} \mathrm{Rn}$ products and their location in the environment depend on the "behaviour" of the first radon decay product ${ }^{218} \mathrm{Po}$. This "behaviour" is conditioned by such processes as cluster formation, neutralization of electric charge, attachment to the aerosol particles, and deposition on the surfaces. The electric charge of a particle with ${ }^{218}$ Po nuclides has a big impact on these processes and on the spectrum of radon short-lived decay product bearers (i.e. aerosol particles) [3].

The ${ }^{218}$ Po ions having appeared after the decay of radon are usually positively charged (about $90 \%$ ). Part of ${ }^{218} \mathrm{Po}$ ions are neutralized; therefore, the other part of ions are neutral. ${ }^{218} \mathrm{Po}$ attaches to the aerosol particles which are always in the air in natural environment. Some of ${ }^{218}$ Po ions, attached to the cluster or aerosol particles, deposit on the surface. Processes of attachment to aerosol particles and surfaces depend on clusters, diffusions of aerosol particles, and electric charge [4]. 
The measure of the degree of radioactive equilibrium between radon and its short-lived progeny is defined by the radioactive equilibrium factor (usually named as factor $F$ ). The factor $F$ shows radioactive balance between radon and its progeny. Most of the radon decay products settle on the surfaces of a room and so are removed from the air. A certain amount of them is removed when the room is ventilated. Then there is no radioactive balance between radon and its short-lived decay products in the air [5].

The radioactive equilibrium factor is expressed [6, 7] as

$$
F=\frac{C_{\mathrm{eq}}}{C_{0}},
$$

where $C_{0}$ is the radon volumetric activity $\left(\mathrm{Bq} \mathrm{m}^{-3}\right)$.

An equivalent equilibrium concentration $C_{\text {eq }}$ is computed according to the following formula [6, 7]:

$$
C_{\text {eq }}=0.105 C_{1}+0.516 C_{2}+0.379 C_{3},
$$

where $C_{1}, C_{2}$, and $C_{3}$ are ${ }^{218} \mathrm{Po},{ }^{214} \mathrm{~Pb}$, and ${ }^{214} \mathrm{Bi}$ volumetric activities in the air $\left(\mathrm{Bq} \mathrm{m}^{-3}\right)$.

Another important parameter that characterizes radon progeny indoors is the unattached fraction factor, which shows which part of radon decay products is not settled on aerosol particles in accommodations [8]. The unattached fraction factor of radon progeny is expressed as

$$
f_{i}=\frac{C_{\mathrm{eq}}^{i}}{C_{i}},
$$

where $C_{\mathrm{eq}}^{i}$ is volumetric activity of $i$ th radon decay product unattached to aerosol particles.

The aim of this work was to measure the radon shortlived decay product volumetric activity, to evaluate the impact of aerosol concentration on variations of radon short-lived decay product volumetric activity inside an individual house, to calculate the radioactive equilibrium factor and define its dependence on aerosol concentration in accommodations.

\section{Methods}

The aerosol particle concentration was measured with an optical aerosol particle counter AZ-5. The equipment AZ-5 uses optical (light scattering) method for pollutant detection and can rate a dispersive constant of aerosol particles with size from 0.4 to $10 \mu \mathrm{m}$. An electrical part, optical sensor, and pneumatic unit comprise the device. The optical sensor AZ-5 creates an electric pulse for each particle. The amplitude depends on the particle size. The pneumatic device is designed to pump the air through the measuring zone of the optical sensor (proper capacity is $1.21 \mathrm{~min}^{-1}$ ). AZ-5 measures the particle number concentration in the range from 0 to $3 \cdot 10^{6}$ particles in litre. According to the manual, the possible systematic error is $\pm 20 \%$.

The aerosol counter is attached to the computer, to which data are sent and recorded [9]. With the help of a data logger ADC-16 the data of continuous measurements are accumulated in the computer. The concentration of aerosol particles and its alterations are constantly controlled (Fig. 1).

Simultaneously the volumetric activities of radon short-lived decay products were measured. For that purpose the hourly measurement method of the radon progeny volumetric activity in the air was used [9]. A radiometer GM-45, which measures the activity of a filter band through which the air is sucked, was installed in an airtight metal frame. The radiometer data were constantly recorded and sent to the computer. The time of suction and the time when the filter band is turned are programmed with the help of electronic stopwatches (Fig. 1).

The radiometer GM-45 contains a Geiger-Müller tube capable of detecting alpha, beta, and gamma/X-ray radiation (alpha above $3 \mathrm{MeV}$, beta above $50 \mathrm{keV}$, gamma/X-ray above $7 \mathrm{keV}$ ). The diameter of isinglass is $42 \mathrm{~mm}$. A copy of RAD (Radiation Acquisition and Display) software for reading and storing data as well as creating graphs and analysing trends is included with GM-45.

The radiometer is fixed in the metal frame so that the filter band through which the air is sucked moves beside the radiometer measurement window (Fig. 1).

Metal frame $\left(340 \times 230 \times 220 \mathrm{~mm}^{3}\right)$ has inlet and outlet. Inlet is used for air suction. A pump is attached to the outlet. The diameter of the air inlet is $20 \mathrm{~mm}$. The air suction rate is $401 \mathrm{~min}^{-1}$ and it is controlled by air flow meter. The air passes through the device during 25 seconds. The air is sucked through the part of filter band which is between a suction channel and a radiometer. The band is stopped at the time of measurement. When the measurement is over, the band is overwound so that the "clean" (i. e. without radon progenies) part of the filter appears above the radiometer and the air suction channel of the pump. The radiation of the particles, settled on the filter, is measured with the radiometer GM-45. Equipment operation can be programmed in various ways: the suction or measurement time can be changed or the measurement can be done after a cer- 


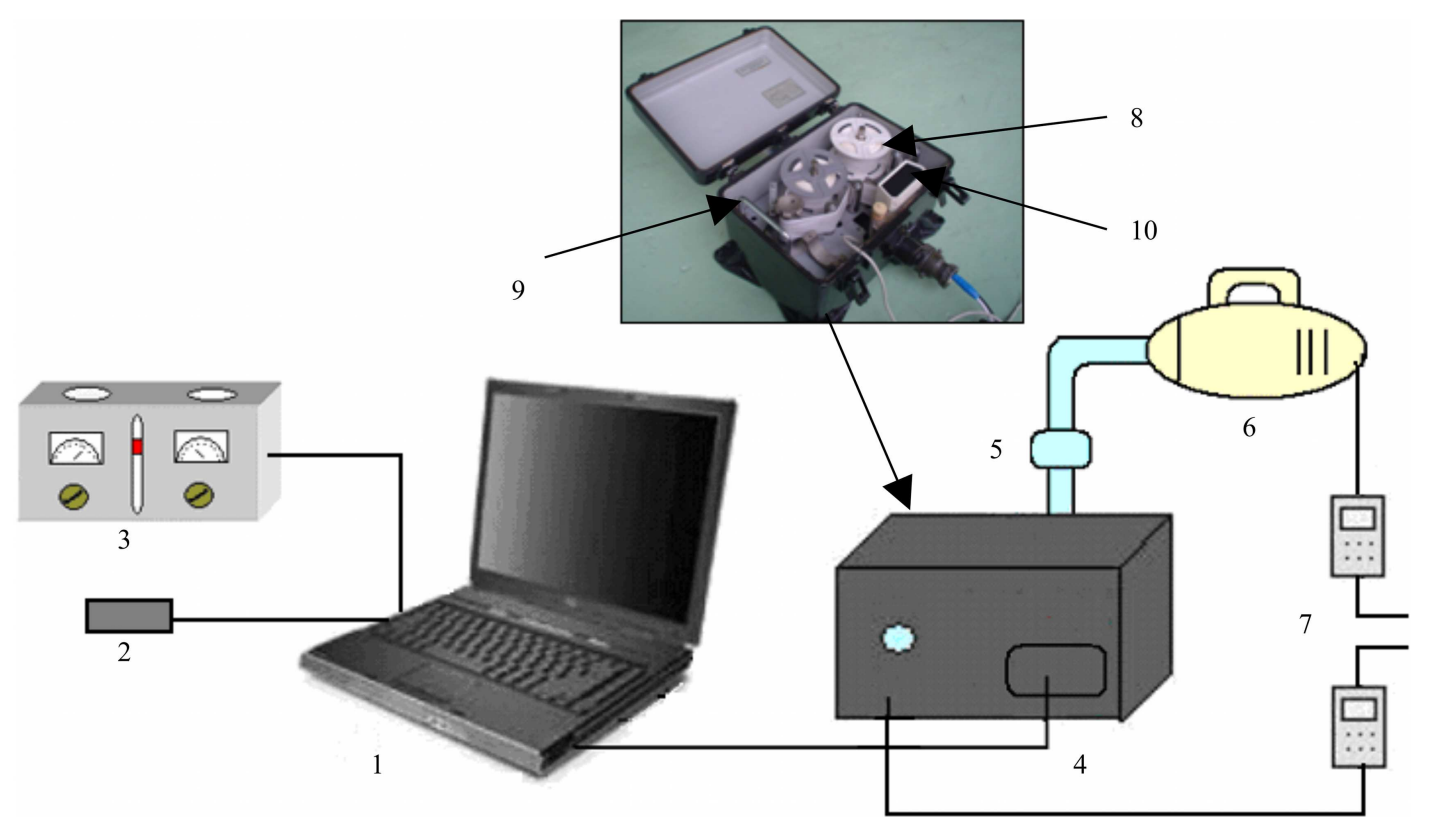

Fig. 1. Set-up for aerosol concentration and radon short-lived decay product volumetric activity measurements in the air: 1 computer, 2 multifunctional data logger, 3 aerosol particle counter, 4 measurement device, 5 air flow meter, 6 air pump, 7 timers, 8 filter band, 9 filter band speed regulator, 10 radiometer.

tain period after the suction (e. g. when there is a need for ${ }^{218}$ Po to be fully decayed).

The concentration of particles attached to aerosol and "free" nuclides of radon progeny and their small clusters in the air are assessed by plugging in and then unplugging the collector of "free" nuclides and clusters to the entrance of the air flow in the measurement device. This collector is made of 10 layers of a wire (the diameter is $0.2 \mathrm{~mm}$ ) net bundle. The net bundle is connected to soil so that the charged nuclides can deposit on the surface of the wire more efficiently. The free positively charged nuclides of ${ }^{218} \mathrm{Po}$ and other short-lived decay products and small clusters due to high mobility deposit on the surface of the net wire. The nuclides attached to aerosol particles pass the net bundle; they are collected by the filter band "Fiberglaz" where after the radioactive decay they are registered with the radiometer.

In order to evaluate the seasonal value of radioactive equilibrium factor between radon and its progeny in the investigated house, the measurements were carried out for one year in the middle of each month. Later the average of three months of each season was calculated.

\section{Results}

The measurements were carried out in an individual house in the south-east of Lithuania, in Šalčininkai area, Jašiūnai town. The house is approximately 100 metres from Lyda highway, surrounded by forests. There is a pinewood on the north side and a deciduous tree forest on the south side of the house, about 70 metres away from its territory. The river Merkys is about 30 metres from the house territory. The 10-year house is made of stone and is two-storied. There is a cellar under the house.

First of all the average radon progeny volumetric activity was measured on all the floors. The average volumetric activity of radon short-lived decay products in the cellar of the individual house was $65 \pm 5 \mathrm{~Bq} \mathrm{~m}^{-3}$, on the ground floor it was $53 \pm 4 \mathrm{~Bq} \mathrm{~m}^{-3}$, on the 1 st floor $39 \pm 4 \mathrm{~Bq} \mathrm{~m}^{-3}$.

Considering the measurement results in the cellar, ground, and 1st floors, it can be stated that the main source of radon progeny in the investigated house is the soil under the house.

The results indicate that the average radon progeny volumetric activity inside this individual house is $52 \mathrm{~Bq} \mathrm{~m}^{-3}$ [10]. The average radon progeny volumetric activity in individual houses in Lithuania is about $56 \mathrm{~Bq} \mathrm{~m}^{-3}$ [1], whereas according to Lithuanian hygienic norms the radon volumetric activity should not be higher than $200 \mathrm{~Bq} \mathrm{~m}^{-3}$ in new houses and $400 \mathrm{~Bq} \mathrm{~m}^{-3}$ in already built houses.

Further measurements were carried out on the ground floor of the house. It was chosen because inhabitants of the house spent most of their time on this floor. There are bedrooms on the 1st floor.

The measurements were carried out in all rooms of the ground floor. The average volumetric activities of 
Table 1. Average volumetric activities of radon short-lived decay products in various rooms, $\mathrm{Bq} \mathrm{m}^{-3}$.

\begin{tabular}{lccc}
\hline Compartment & ${ }^{218} \mathrm{Po}$ & ${ }^{214} \mathrm{~Pb}$ & ${ }^{214} \mathrm{Bi}$ \\
\hline Kitchen & $48 \pm 9$ & $34 \pm 7$ & $21 \pm 4$ \\
Sitting-room & $52 \pm 10$ & $36 \pm 7$ & $23 \pm 5$ \\
Workroom & $46 \pm 9$ & $33 \pm 6$ & $20 \pm 4$ \\
Anteroom & $20 \pm 4$ & $16 \pm 3$ & $9 \pm 2$ \\
\hline
\end{tabular}

radon short-lived decay products in various rooms are presented in Table 1.

It is seen that the average volumetric activities of radon progeny in the anteroom are lower than in other rooms. The anteroom is almost unheated and less isolated from the outside. More intensive change of air from inside and outside results in lower radon progeny volumetric activities in this room. As shown in Table 1, the purpose of other rooms has no impact on the volumetric activities of radon short-lived decay products. Volumetric activities in various rooms may differ. If the doors of the rooms to which radon passes through the soil are airtight, radon progeny volumetric activity in the other rooms is lower when those doors are closed. Furthermore, if the house is not airtight enough, the concentration of radon in different rooms changes a lot due to wind direction and speed. In order to estimate the average volumetric activity of radon short-lived decay products of the whole house more precisely, the measurements should be taken in as many rooms of this house as possible.

In order to characterize the behaviour of radon shortlived decay products in the premises better, the research in the compartments of the individual house was carried out under ordinary living conditions (i.e. burning a candle or frankincence in the rooms, in smokedfilled rooms, in a steamy kitchen after cooking). Under such conditions the concentration of aerosol particles was higher.

The first measurements were carried out in one of the ground floor rooms. During the investigation the temperature and relative humidity of the room were sta- ble, about $20^{\circ} \mathrm{C}$ and $45 \%$, respectively. The average concentration $N$ of aerosol particles in the room was $1.2 \cdot 10^{3} \mathrm{~cm}^{-3}$. The concentration of aerosol particles increased sharply (up to $1.0 \cdot 10^{6} \mathrm{~cm}^{-3}$ ) when the room was smoke-filled, a candle or frankincence were burnt, and it was steamy after cooking in the room. The ventilation intensity in the room was about $0.25 \mathrm{~m}^{3} \mathrm{~h}^{-1}$. The results of measurements obtained under natural conditions and using the aerosol sources are presented in Table 2, where statistical averages are shown.

Under natural environmental conditions the value of unattached fraction factor $f_{\mathrm{Po}}$ altered from 0.09 to 0.70 , and the average obtained value was $0.32 \pm 0.02$. The average value of radioactive equilibrium factor $F$ was 0.17 , and its values varied from 0.05 to 0.50 . Such a low value of the radioactive equilibrium factor is due to low concentration of aerosol particles in the air in premises. When the concentration of aerosol particles in premises is low, very few radon progeny are attached to particles. Therefore, radon short-lived products having appeared after the decay are usually free, unattached, and settle on the surface. This causes the absence of balance between radon and its progeny.

In the course of time the large part of radon progeny settle on walls, furniture, etc. In this way they are removed from the air. A certain part of them is removed by ventilation. Therefore, after a longer period of time the values of measurements change. The change of aerosol particle concentration in the air, the unattached fraction factor, and the radioactive equilibrium factor dependence on time is shown in Fig. 2.

The radon volumetric activity $C$, the radioactive equilibrium factor $F$, the unattached fraction factor $f_{\mathrm{Po}}$, and concentration $N$ of aerosols in the air were measured in 6 different rooms of the individual house (also on the ground and first floors) under usual conditions (ventilated premises, unaired premises). The results are presented in Table 3.

The statistical bias of the radon volumetric activity measurement reached $15 \%$. The values of radon volumetric activities altered from 18 to $170 \mathrm{~Bq} \mathrm{~m}^{-3}$. The

Table 2. Aerosol concentration in the air $N$, unattached fraction factors $f_{\mathrm{Po}}$, and radioactive equilibrium factors $F$ under the different aerosol conditions indoors (35 measurements in total).

\begin{tabular}{lccc}
\hline Aerosol sources & $N, 10^{3} \mathrm{~cm}^{-3}$ & $f_{\mathrm{Po}}$ & $F$ \\
\hline Natural conditions & $1.2 \pm 0.10$ & $0.320 \pm 0.020$ & $0.17 \pm 0.01$ \\
Smoking & $90 \pm 6.30$ & $0.027 \pm 0.002$ & $0.62 \pm 0.05$ \\
Candles & $380 \pm 30.40$ & $0.031 \pm 0.002$ & $0.32 \pm 0.03$ \\
Frankincense & $120 \pm 9.60$ & $0.025 \pm 0.001$ & $0.51 \pm 0.04$ \\
Cooking & $240 \pm 14.40$ & $0.043 \pm 0.003$ & $0.25 \pm 0.02$ \\
\hline
\end{tabular}


Table 3. Measured values of volumetric activities of radon $C$, unattached fraction factors $f_{\mathrm{Po}}$, radioactive equilibrium factors $F$, and aerosol concentrations in the air $N$ in various compartments of the individual house.

\begin{tabular}{ccccc}
\hline No. & $C, \mathrm{~Bq} \mathrm{~m}^{-3}$ & $f_{\text {Po }}$ & $F$ & $N, 10^{3} \mathrm{~cm}^{-3}$ \\
\hline 1 & $45 \pm 6$ & $0.12 \pm 0.02$ & $0.72 \pm 0.06$ & $2.8 \pm 0.22$ \\
2 & $65 \pm 9$ & $0.09 \pm 0.02$ & $0.33 \pm 0.03$ & $3.2 \pm 0.22$ \\
3 & $18 \pm 3$ & $0.05 \pm 0.01$ & $0.34 \pm 0.03$ & $3.8 \pm 0.30$ \\
4 & $43 \pm 4$ & $0.08 \pm 0.02$ & $0.37 \pm 0.03$ & $3.4 \pm 0.27$ \\
5 & $32 \pm 4$ & $0.08 \pm 0.02$ & $0.37 \pm 0.03$ & $3.4 \pm 0.20$ \\
6 & $105 \pm 12$ & $0.20 \pm 0.04$ & $0.23 \pm 0.02$ & $1.7 \pm 0.20$ \\
7 & $170 \pm 16$ & $0.15 \pm 0.02$ & $0.18 \pm 0.02$ & $2.4 \pm 0.19$ \\
8 & $70 \pm 10$ & $0.03 \pm 0.01$ & $0.55 \pm 0.04$ & $4.2 \pm 0.25$ \\
\hline
\end{tabular}

values of the radioactive equilibrium factor were between 0.18 and 0.72 , the calculated average value was $0.34 \pm 0.03$. The average absolute bias of measured concentrations of aerosol particles was $8 \%$. The values of the unattached fraction factor varied from 0.03 to 0.15 , the calculated average value was $0.10 \pm 0.02$. Table 3 shows that unattached fraction factors of radon progeny are lower when the concentration of aerosol particles in premises is higher. Using the received data an inverse relationship between unattached fraction factor and radioactive equilibrium factor was determined (see Fig. 2), except when ventilation was used. A tight connection (correlation coefficient $r=0.9$ ) between the radioactive equilibrium factor and aerosol particle concentration in the air was determined. The higher the aerosol particle concentration, the higher is the radioactive equilibrium factor, as the process of attachment becomes faster than the deposition of unattached particles on the surface. However, when the concentration of aerosol particles is higher, the balance is not attained $(F=1)$, because a certain amount of attached aerosol particles is lost due to deposition on walls and furniture.

Figure 2 shows an example of a typical change of the unattached fraction factor and the radioactive

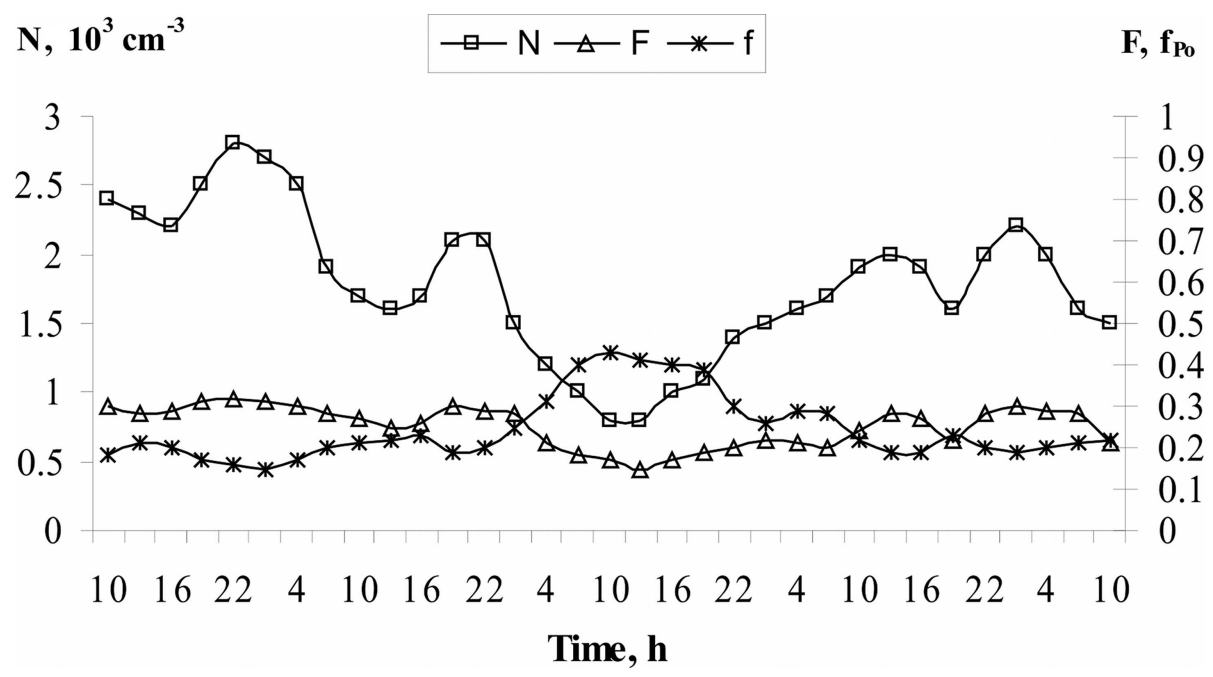

Fig. 2. Variation of unattached fraction factor $f_{\mathrm{Po}}$, radioactive equilibrium factor $F$, and aerosol particle concentration in the air $N$ under natural living conditions.

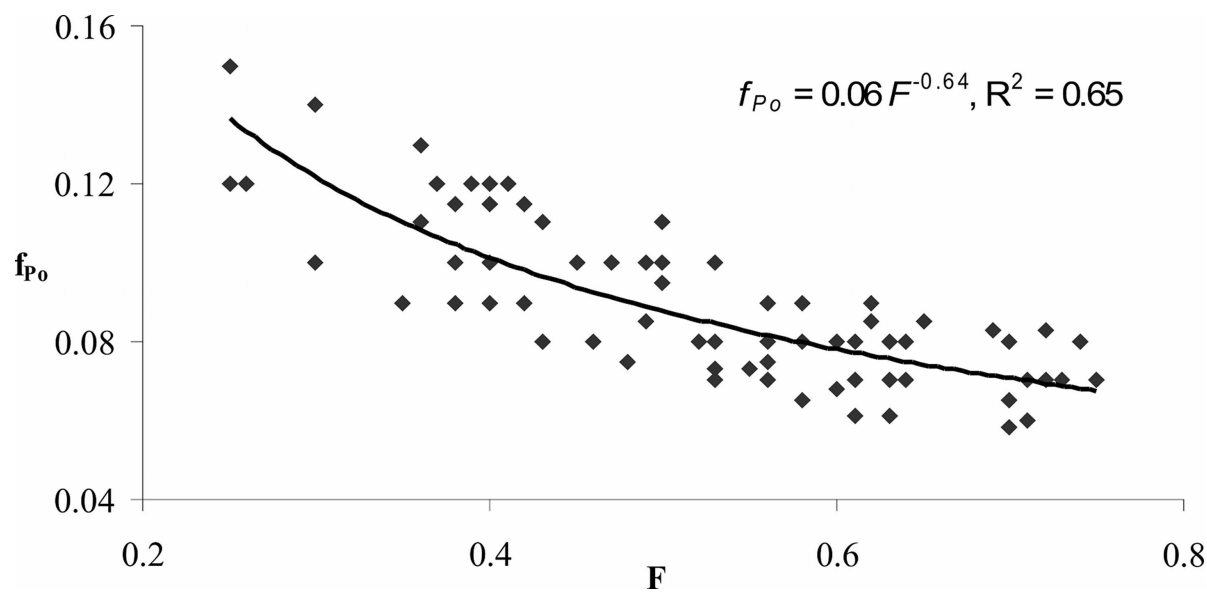

Fig. 3. Correlation between the unattached fraction factor $f_{\text {Po }}$ and the radioactive equilibrium factor $F$. 
equilibrium factor when the concentration of aerosol particles in the air of premises varies.

Increase of unattached fraction factor is observed (from 0.15 to 0.40 ) while the concentration of aerosol particles is decreasing from approximately $2.5 \cdot 10^{3}$ to $0.5 \cdot 10^{3} \mathrm{~cm}^{-3}$. It is seen that after the decrease of aerosol concentration in the air the lower values of the radioactive equilibrium factor are obtained $(0.15-0.20)$. Using aerosol sources the unattached fraction becomes insignificant, the factors are 0.03-0.05. On the other hand, the equilibrium factor increased a lot, its values were $0.8-0.9$, sometimes the values reached 0.95 .

Attempts were made to investigate the dependence of the unattached fraction factor on the radioactive equilibrium factor (Fig. 3).

The negative correlation between the unattached fraction factor and the radioactive equilibrium factor was obtained, which can be expressed as $f_{\mathrm{Po}}=$ $0.06 F^{-0.64}$. Such dependence was determined during all measurements.

The seasonal data of the radioactive equilibrium factor between radon and its progeny varied from 0.43 to 0.52 in the investigated house. With a change of the aerosol amount in the premises the radioactive equilibrium factor also changes. In the smoke-filled premises the values of radioactive equilibrium factor reached $0.7-0.8$.

The seasonal average values of the radioactive equilibrium factor in the premises are presented in Table 4.

Table 4. Seasonal data of radioactive equilibrium factor in the investigated accommodations.

\begin{tabular}{lccc}
\hline \multirow{2}{*}{ Season } & \multicolumn{3}{c}{$F$} \\
\cline { 2 - 4 } & Minimum & Maximum & Average \\
\hline Spring & 0.09 & 0.9 & 0.49 \\
Summer & 0.08 & 0.9 & 0.43 \\
Autum & 0.09 & 0.9 & 0.45 \\
Winter & 0.02 & 0.9 & 0.52 \\
\hline
\end{tabular}

The measured radioactive equilibrium factors are higher in winter and lower in summer. Such seasonal change of the radioactive equilibrium factors is due to different ventilation in the accommodations.

The radioactive equilibrium factors are higher in winter if the accommodations are not ventilated, and the house is airtight. This allows radon and its progeny to accumulate, therefore, the radioactive equilibrium factor between radon and its progeny is increasing. In summer accommodations are well ventilated and this lowers the radioactive equilibrium factor between radon and its progeny.

Most frequently recurring values of the radioactive equilibrium factor are $0.4-0.5$. The radioactive equilibrium factor is used as a factor "to transfer" the radon volumetric activity to its progeny volumetric activity in premises, and vice versa. With a known radioactive equilibrium factor the effective dose caused by radon in the accommodations can be calculated.

The obtained measurement values of radioactive equilibrium factor are similar to the values calculated in Holland and Germany. It is noticed that the radioactive equilibrium factor in northern countries is higher than in tropical countries [11, 12]. However, due to a wide range of radioactive equilibrium variations in different places, it is recommended to calculate it separately for specific regions.

\section{Conclusions}

1. Volumetric activities of radon short-lived decay products in various compartments of the investigated individual house were determined. Measured average volumetric activities of ${ }^{218} \mathrm{Po},{ }^{214} \mathrm{~Pb}$, ${ }^{214} \mathrm{Bi}$ were lower in anteroom than in the other rooms. The anteroom is less isolated from the outside, so more intensive change of air from inside and outside caused lower radon progeny volumetric activities in this compartment.

2. Considering the results of measurements in the cellar, on the ground and 1st floors of the house, it has been determined that the main source of radon progeny in the investigated individual house is the soil under the house. The irradiance of the radon progeny can be reduced by sealing up the layer between the soil and the building and ventilating accommodations better.

3. The measured values of the radioactive equilibrium factor in normally ventilated accommodations varied from 0.4 to 0.5 , and in a smokefilled compartments they often reached 0.7-0.8. Therefore there is a higher possibility to inhale radon progeny and damage organism in the smoking premises.

4. It has been determined that radioactive equilibrium factor is lower in summer than in other seasons. Such seasonal change of the radioactive equilibrium factor is due to the more ventilated accommodations in summer.

5. The values of the unattached fraction factor in the individual house varied from 0.03 to 0.15 , and the 
concentration of aerosol particles from $1.2 \cdot 10^{3}$ to $3.8 \cdot 10^{3} \mathrm{~cm}^{-3}$ under natural conditions. Higher volumetric activity of alpha particles was registered when increasing the concentration of aerosol particles in the air, as the amount of attached free nuclides of radon short-lived decay products to aerosol particles increases.

6. The positive correlation coefficient $r=0.9$ between the radioactive equilibrium factor and concentration of aerosol particles in the accommodations and a negative correlation coefficient between the radioactive equilibrium factor and unattached fraction factor were determined.

\section{References}

[1] B. Clavensjo, G. Akerblom, and G. Morkūnas, Radonas patalpose. Jo kiekio mažinimo būdai (Litima, Vilnius, 1999) [Radon Indoors. Its Reduction Techniques, in Lithuanian].

[2] A. Mohamed, Study on radon and radon progeny in some living rooms, Radiat. Protect. Dosim. 117(4), 402-407 (2005).

[3] J. Porstendorfer, Properties and behaviour of radon and thoron and their decay products in the air, J. Aerosol Sci. 25(2), 219-263 (1994).

[4] J. Porstendorfer, P. Pagelkopf, and M. Grundel, Fraction of the positive ${ }^{218} \mathrm{Po}$ and ${ }^{214} \mathrm{~Pb}$ clusters in indoor air, Radiat. Protect. Dosim. 113(3), 342-351 (2005).
[5] C.S. Li and E.K. Hopke, Air filtration and radon decay product mitigation, Indoor Air 2(2), 84-100 (1992).

[6] A. Mohamed, Influence of radioactive aerosol and biological parameters of inhaled radon progeny on human lung dose, Radiat. Protect. Dosim. 113(1), 115122 (2005).

[7] C. Baixeras, K. Amgarou, Ll. Font, and C. Domingo, Long-term radon levels and equilibrium factor in some Spanish workplaces measured with a passive integrating detector, Radiat. Protect. Dosim. 85(1-4), 233-236 (1999).

[8] K.N. Yu, E.C.M. Young, and K.C. Li, A study of factors affecting indoor radon properties, Health Phys. 71(2), 179-184 (1996).

[9] D. Jasaitis and A. Girgždys, Hourly measurement method for radon progeny volumetric activity in air, J. Environ. Eng. Landsc. Manag. 15(3), 158-165 (2007).

[10] D. Politova and D. Jasaitis, The influence of aerosol concentration on changes in the volumetric activities of indoor radon short-term decay products, Sci. Future Lith. 2(5), 81-86 (2010).

[11] A. Cavallo, The radon equilibrium factor and comparative dosimetry in homes and mines, Radiat. Protect. Dosim 92(4) 295-298 (2000)

[12] î̀. Ǩreuzer, J. Heinrich, G. Wölke, A. Rosario, M. Gerken, J. Wellmann, G. Keller, L. Kreienbrock, and H. Wichmann, Residential radon and risk of lung cancer in Eastern Germany, Epidemiology 14(5), 559568 (2003).

\title{
AEROZOLIO DALELIŲ KONCENTRACIJOS İTAKA RADONO SKILIMO PRODUKTŲ TŪRINIAM AKTYVUMUI PATALPOSE
}

\author{
D. Jasaitis, A. Girgždys \\ Vilniaus Gedimino technikos universitetas, Vilnius, Lietuva
}

\begin{abstract}
Santrauka
Tirta aerozolio daleliu skaitinès koncentracijos įtaka radono trumpaamžių skilimo produktų tūrinio aktyvumo pokyčiui gyvenamosiose patalpose. Išmatuoti radono ir jo trumpaamžiu skilimo produktų tūriniai aktyvumai patalpose įvairiomis gyvenimo sąlygomis. Ivertintos aerozolio dalelių koncentracijos ore, radioaktyviosios pusiausvyros koeficiento ir laisvosios frakcijos koeficiento vertès įprastomis gyvenimo sąlygomis bei dirbtinai padidinus aerozolio dalelių koncentraciją ore. Nustatyta, kad patalpoje deginant žvakę
\end{abstract}

ar smilkalus, rūkant, gaminant valgi, padaugejja laisvụjų radono trumpaamžių skilimo produktų atomų, prisijungusiu prie aerozolio dalelių. Šiuo atveju registruotas didesnis alfa dalelių tūrinis aktyvumas. Nustatyta neigiama laisvosios frakcijos koeficiento ir radioaktyviosios pusiausvyros koeficiento koreliacija. Gauta teigiama radioaktyviosios pusiausvyros koeficiento ir aerozolio daleliu koncentracijos patalpu ore koreliacija. Pateikiami radioaktyviosios pusiausvyros koeficiento sezoniniai pokyčiai. 